\title{
SEPARATION AND PROPERTIES OF HYALURONIDASE FROM RAM SPERM ACROSOMES
}

\author{
GHUL HAK YANG AND P. N. SRIVASTAVA \\ Reproduction Research Laboratory, Department of Biochemistry, \\ University of Georgia, Athens, Georgia 30602, U.S.A.
}

(Received 27th March 1973)

\begin{abstract}
Summary. Ram sperm acrosomes were disrupted by Hyamine and Triton treatment and extracts were initially fractionated with a Sephadex G-100 column at $\mathrm{pH} 3.5$. Acrosin, a proteolytic enzyme, was completely separated from hyaluronidase by this step. Highly active hyaluronidase, specific activity of 1320 units/mg protein $(38,280$ National Formulary units/mg protein), was obtained by DEAE chromatography but two minor contaminants were present. The partially purified enzyme had an optimum at $\mathrm{pH} 4 \cdot 3$. The enzyme showed no activity at $\mathrm{pH} 3.0$ and only $10 \%$ of its activity at $\mathrm{pH} 8.0$. Heparin and chondroitin sulphate $\mathrm{B}$ inhibited $50 \%$ of its activity. The molecular weight was estimated to be 62,000 by sodium dodecyl sulphate gel electrophoresis.
\end{abstract}

\section{INTRODUCTION}

Acrosomal extracts of mammalian spermatozoa obtained with detergents contain hyaluronidase (Srivastava, Adams \& Hartree, 1965; Stambaugh \& Buckley, 1968; Zaneveld, Polakoski \& Schumacher, 1973). Stambaugh \& Buckley (1969) reported that in the acrosomal extract of rabbit spermatozoa, hyaluronidase is associated with a trypsin-like enzyme. The trypsin-like enzyme was later designated as acrosin because of its substrate specificity and other properties (Zaneveld, Polakoski \& Williams, 1972; Polakoski, Zaneveld \& Williams, 1972). Hyaluronidase is involved in the dispersal of the cumulus and is being extensively studied as an effective isoantigen in the female that is inhibited by isoantibodies (Metz, 1972). Zaneveld et al. (1973) partially purified hyaluronidase from bull spermatozoa and demonstrated its resemblance to bull testicular hyaluronidase.

The partially purified enzyme obtained by Zaneveld et al. (1973) is several times less active than the hyaluronidase present in the crude acrosomal extract of ram spermatozoa. In this paper, we describe methods for separating acrosin and hyaluronidase and the partial purification and properties of ram sperm acrosomal hyaluronidase. 


\section{MATERIALS AND METHODS}

Materials

Ram semen was collected by electroejaculation. Hyaluronic acid (Grade III-P, Lot 51C-2270); DEAE-cellulose (medium mesh, Lot 30C-2390); chondroitin sulphate A, B, C; heparin and p-dimethyl-aminobenzaldehyde were purchased from Sigma Chemical Co. Sephadex G-100 in bead form (40 to $120 \mu \mathrm{m}$ ) was obtained from Pharmacia Fine Chemicals. Benzoyl arginine ethyl ester (BAEE) was the product of Schwarz/Mann Co. Azocoll (general proteolytic substrate) was obtained from Calbiochem. National Formulary standard hyaluronidase $(8 \cdot 8$ units $/ \mathrm{mg})$ was obtained from the Committee on National Formulary of the American Pharmaceutical Association. All other chemicals were of the highest purity available.

\section{Methods}

Hyaluronidase assay. Hyaluronidase activity was determined colorimetrically by a modification of the method of Aronson \& Davidson (1967a). The reaction was carried out in a total volume of $0.5 \mathrm{ml}$ containing $0.2 \mathrm{ml}(6 \mathrm{mg} / \mathrm{ml})$ hyaluronic acid, $0.1 \mathrm{ml}$ of $0.1 \mathrm{M}$-sodium acetate buffer, $\mathrm{pH} 3.8,0.1 \mathrm{ml}$ of $2.0 \mathrm{M}-\mathrm{NaCl}$ and $0.1 \mathrm{ml}$ of the enzyme. The solution was incubated at $37^{\circ} \mathrm{C}$ for $1 \mathrm{hr}$. After incubation, the $\mathrm{pH}$ of the reaction mixture was adjusted to approximate neutrality by addition of $0.01 \mathrm{ml}$ of $4 \mathrm{~N}-\mathrm{NaOH}$ and $0.1 \mathrm{ml}$ of $0.8 \mathrm{M}$-potassiumtetraborate $(\mathrm{pH} 9)$. The reaction was then stopped by heating at $100^{\circ} \mathrm{C}$ for $8 \mathrm{~min}$. The $\mathrm{N}$-acetyl-hexosamine end-group colour was estimated by the method of Reissig, Strominger \& LeLoir (1955) using N-acetyl-glucosamine as standard. The colour was allowed to develop for $20 \mathrm{~min}$ at $37^{\circ} \mathrm{C}$ to obtain the maximum chromogen formation. One unit equals $1 \mu \mathrm{mol} \mathrm{N}$-acetyl-glucosamine released per min. The National Formulary Standard for hyaluronidase contains 230 N.F. units $/ \mathrm{mg}$ protein and $1 \mathrm{mg}$ protein of the standard was equivalent to 7.93 units in colorimetric assay. Thus, one unit of activity obtained by this method is equivalent to $29 \cdot 0$ N.F. units.

Other assays. Acrosin activity was measured by the spectrophotometric method of Schwert \& Takenaka (1955), using BAEE as substrate. Assays were performed in $0.05 \mathrm{M}$-tris- $\mathrm{HCl}$ buffer at $\mathrm{pH} 8.0$ containing $0.05 \mathrm{M}-\mathrm{CaCl}_{2}$. One unit of acrosin activity was defined as an absorbance change of 1 optical density/ $\min$ at $253 \mathrm{~nm}$. Azocoll hydrolysis was determined by the method described in Calbiochem Document No. 3805 (Cat. No. 19493).

Biuret reagent was used for detecting high concentrations of protein according to the procedure of Gornall, Bardawill \& David (1949) and protein in the range of 10 to $200 \mu \mathrm{g}$ was determined by the method of Lowry, Rosebrough, Farr \& Randall (1951), using bovine serum albumin (Pentex Co.) as standard.

Preparation of acrosomal extracts. Ram acrosomal extracts were prepared by the method of Hartree \& Srivastava (1965) and Srivastava, Zaneveld \& Williams (1970). Washed spermatozoa were treated with cationic detergent Hyamine 2389 (Rohm \& Haas) and Triton X-100. The detergent extract was precipitated with ethanol, dialysed and freeze-dried. 
Purification of hyaluronidase and acrosin. Step I. Sephadex G-100 chromatography. Freeze-dried ram acrosomal extract was dissolved in $0.1 \mathrm{M}-\mathrm{NaCl}$, adjusted to pH 3.5 with $\mathrm{HCl}$, and applied to a Sephadex G-100 column $(2.5 \times 85 \mathrm{~cm})$ at $4^{\circ} \mathrm{C}$ pre-equilibrated with $0 \cdot 1 \mathrm{M}-\mathrm{NaCl}, \mathrm{pH} 3.5$. The column was washed with $650 \mathrm{ml}$ of $\mathrm{NaCl}$ solution $(0.1 \mathrm{M})$ at the rate of $20.6 \mathrm{ml} / \mathrm{hr}$. The hyaluronidase active fractions were pooled and concentrated to $20 \mathrm{ml}$ by diaflow (Amicon, PM-10 filter) with successive addition of 0.05 m-potassium phosphate buffer $(\mathrm{pH} \mathrm{7.0)}$. The acrosin active fractions were also pooled separately and concentrated by diaflow using 0.05 $\mathrm{M}$-tris- $\mathrm{HCl}, \mathrm{pH} \mathrm{8.0.}$

Step II. DEAE-cellulose chromatography. The hyaluronidase active fraction from Step I was applied to a DEAE-cellulose column $(35 \times 2.5 \mathrm{~cm})$ at $4^{\circ} \mathrm{C}$ pre-

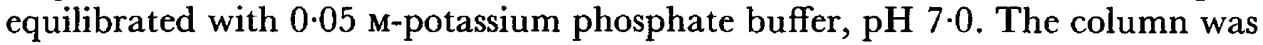
eluted with $450 \mathrm{ml}$ buffer and developed with a stepwise gradient of $0.05 \mathrm{M}$ to $2 \mathrm{M}-\mathrm{NaCl}$ at the rate of $20.5 \mathrm{ml} / \mathrm{hr}$. The first protein peak showing high constant hyaluronidase activity across the peak was pooled and stored at $0^{\circ} \mathrm{C}$.

Molecular weight determination. The molecular weight was estimated by sodium dodecyl sulphate (SDS) gel electrophoresis (Weber \& Osborn, 1969). The protein was treated with $1.0 \%$ SDS to neutralize the charges and with $1 \%$ $\beta$-mercaptoethanol to break all susceptible disulphide bonds. The samples were then subjected to polyacrylamide gel electrophoresis in the presence of $0 \cdot 1 \mathrm{~m}$-SDS. The mobility of the proteins was calculated by the equation of Weber \& Osborn (1969). Ovalbumin, bovine pancreatic trypsin, lysozyme, pepsin and bovine serum albumin were used as references. The molecular weight was plotted against mobility on a semi-log paper.

\section{RESULTS}

Separation of hyaluronidase from acrosin by Sephadex G-100 chromatography

Step I. Ram sperm acrosomal extract averaged 112 units of hyaluronidase activity $/ \mathrm{mg}$ protein and 1.06 units of acrosin $/ \mathrm{mg}$ protein. The major aim of this purification was to separate hyaluronidase from acrosin. As shown in Text-fig. 1, however, several well separated protein peaks were obtained using a long Sephadex G-100 column developed with $0 \cdot 1 \mathrm{~m}-\mathrm{NaCl}$ at $\mathrm{pH} 3 \cdot 5$. Acrosin eluted in the second peak. Both enzymes were in the void volume at $\mathrm{pH} 6$ to 7 on gel filtration. The hyaluronidase fraction (269 units/mg protein, Text-fig. 1) showed only 0.8 units acrosin/mg protein, whereas the acrosin peak had 11.7 units/mg protein. At $\mathrm{pH} 3 \cdot 5$, ram acrosomal hyaluronidase was stable and lost less than $5 \%$ of its activity. After the fractions indicated by the arrow (Text-fig. 1) were collected, the $\mathrm{pH}$ of the solution was adjusted to $\mathrm{pH} 7.0$ with 0.05 M-potassium phosphate buffer.

\section{DEAE-cellulose chromatography}

Step II. Hyaluronidase was eluted after the void volume and the other protein peaks were eluted with increasing salt concentration (Text-fig. 2). The hyaluronidase fractions were free from acrosin activity. The purified hyaluronidase also failed to hydrolyse azocoll, indicating the absence of non-specific proteinases. The purified hyaluronidase showed 1320 units/mg protein, i.e. 38,280 


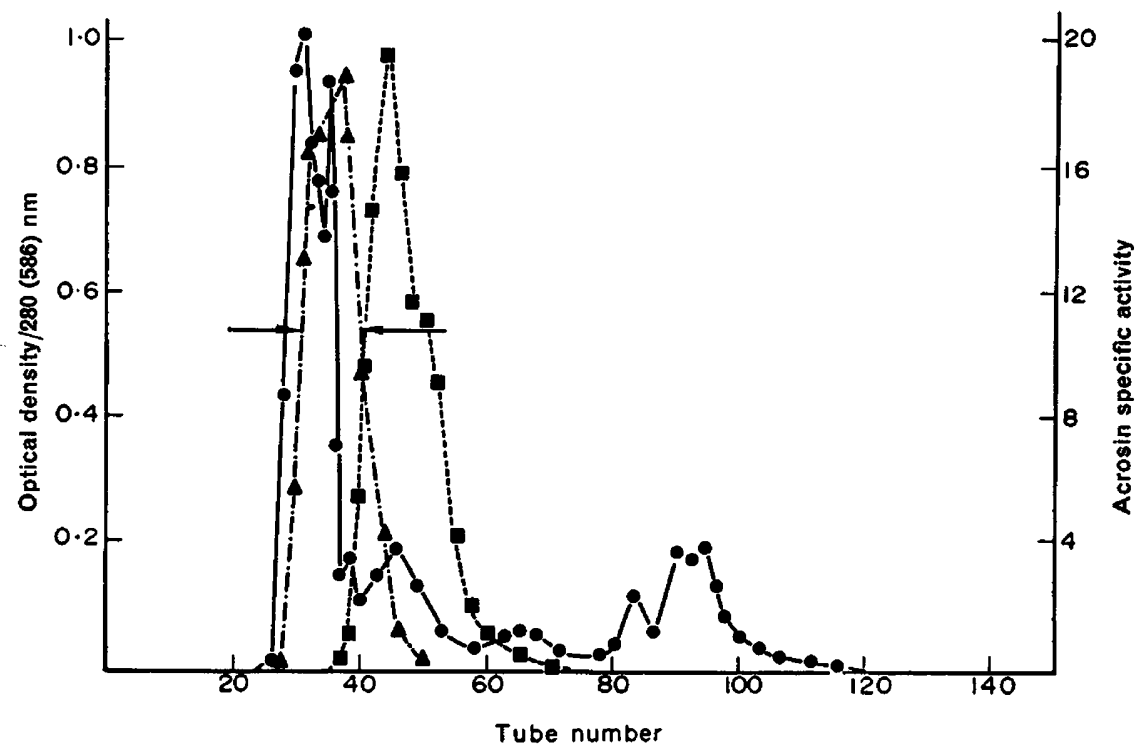

TEXT-FIG. 1. Step I. Elution profile of ram acrosomal extracts purified by Sephadex G-100 column eluting with $0.1 \mathrm{M}-\mathrm{NaCl}(\mathrm{pH} 3.5)$. The column size was $2.5 \times 85 \mathrm{~cm}$ and 5-ml fractions were collected. $\bullet$, Protein; $\Lambda$, hyaluronidase activity; $\boldsymbol{\square}$, acrosin activity.

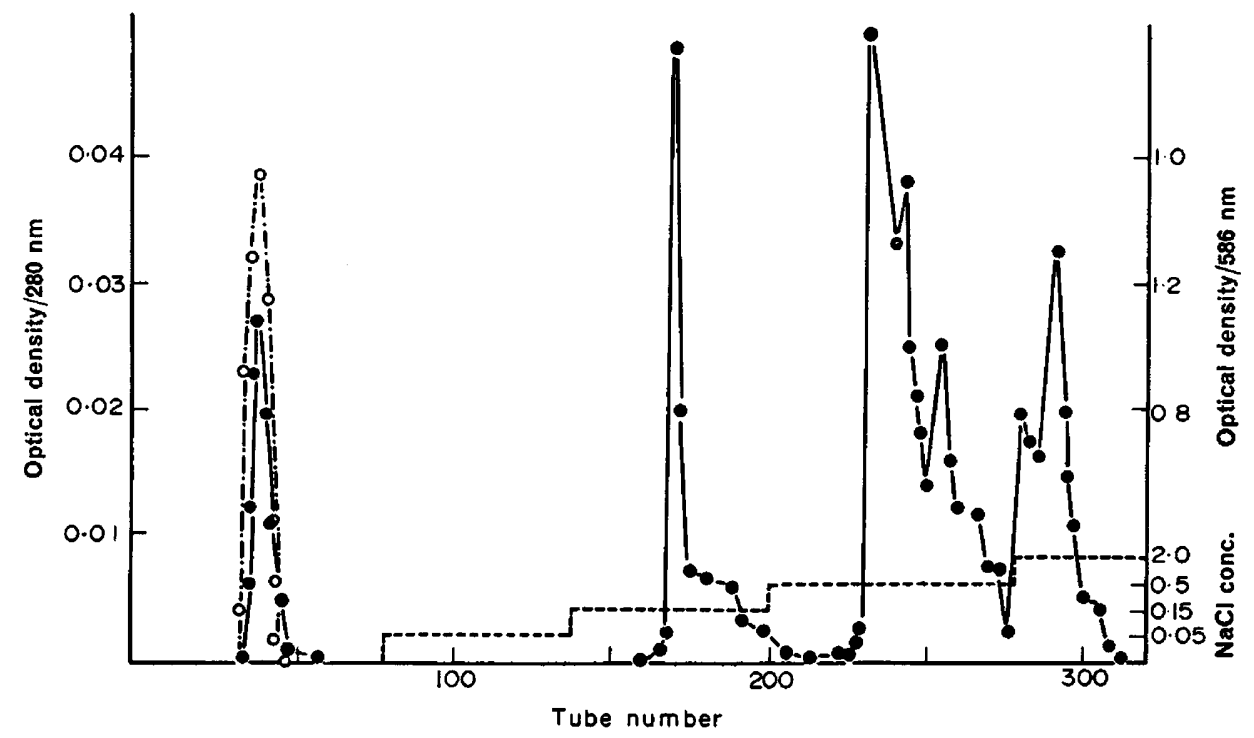

TEXT-FIG. 2. Step II. Elution profile of the active fractions of ram acrosomal extracts from Sephadex G-100 column purified by DEAE-cellulose chromatography. The column was developed with $0.05 \mathrm{~m}$-potassium phosphate buffer, $\mathrm{pH} 7.0$, by a NaCl gradient. The column dimension was $2.4 \times 36 \mathrm{~cm}$ and $5 \mathrm{ml}$ fractions were collected. $\bullet$, Protein; $O$, hyaluronidase activity. 
Table 1. Summary of purification of hyaluronidase from ram acrosomal extracts

\begin{tabular}{l|c|c|c|c|c|c}
\hline \multicolumn{1}{c|}{ Step } & $\begin{array}{c}\text { Total } \\
\text { protein }(\mathrm{mg})\end{array}$ & $\begin{array}{c}\text { Total } \\
\text { activity }\end{array}$ & $\begin{array}{c}\text { Specific } \\
\text { activity* }\end{array}$ & $\begin{array}{c}\text { Relative } \\
\text { activity }\end{array}$ & rield (\%) & $\begin{array}{c}\text { Acrosin } \\
\text { activity } \dagger\end{array}$ \\
\hline Ram acrosomal extracts & 50.57 & 5663 & 112.0 & 1.0 & 100 & 1.06 \\
Sephadex G-100, Step 1 & $11 \cdot 29$ & 3037 & $269 \cdot 0$ & $2 \cdot 4$ & 53.5 & 0.8 \\
DEAE-cellulose column, Step II & 0.96 & 1267 & 1320.0 & 11.8 & 22.4 & 0.0 \\
\hline
\end{tabular}

1 unit $=29$ N.F. units.

* Units/mg protein.

$\dagger$ Optical density units/mg protein (Polakoski et al., 1972).

N.F. units $/ \mathrm{mg}$ protein. These fractions were stored at $-15^{\circ} \mathrm{C}$. The data for purification of hyaluronidase are given in Table 1.

\section{Sodium dodecyl sulphate gel electrophoresis}

The degree of purity was tested by SDS gel electrophoresis. The purified hyaluronidase fraction showed one major band and two minor bands (Plate 1). The two minor bands were presumed to be minor contaminant proteins.

\section{Properties}

pH optimum. As shown in Text-fig. $3, \mathrm{pH} 4.3$ is the optimum for the maximum activity of ram acrosomal hyaluronidase. For $\mathrm{pH}$ studies, the amount of the buffer was doubled and the $\mathrm{pH}$ of the final reaction solution was checked after the conclusion of the reaction.

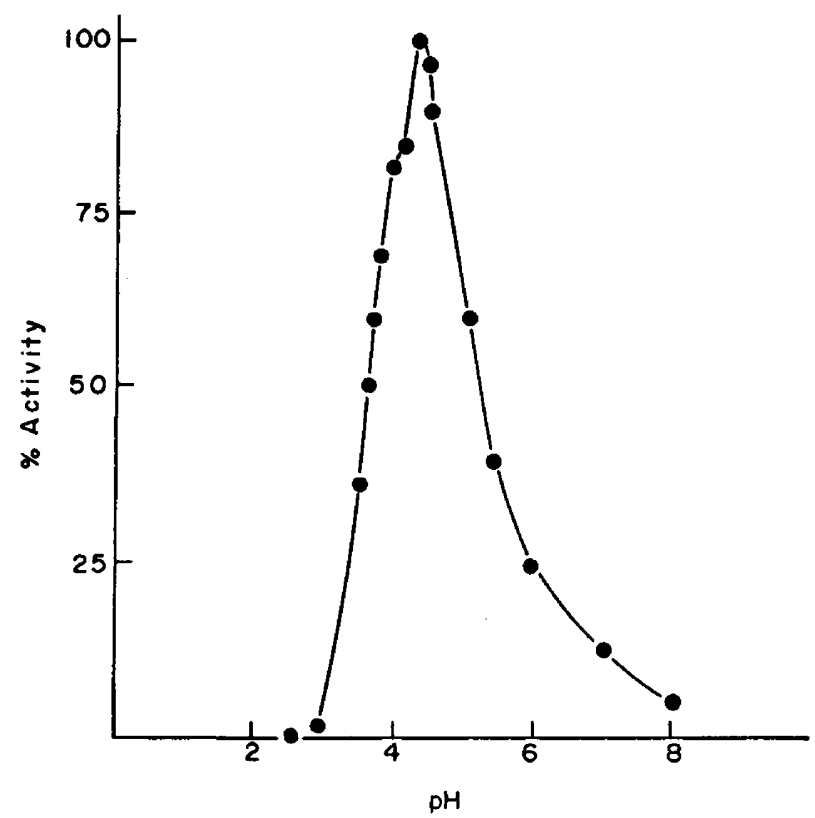

TExT-FIG. 3. The pH optimum of ram acrosomal hyaluronidase. The activity was assayed using the enzyme obtained after DEAE-cellulose column chromatography (1320 units/mg protein). 
Stability. Crude hyaluronidase, i.e. the starting material in solution at $\mathrm{pH} 7$, was stable at room temperature for several days. The purified enzyme in solution lost $36 \%$ of its activity in a week at $4{ }^{\circ} \mathrm{C}$ and $70 \%$ of the activity was lost when stored frozen for a year.

Substrate specificity and inhibition. Chondroitin sulphate A, B and C are hydrolysed by ram acrosomal hyaluronidase. On the other hand, when hyaluronate is used as a substrate, the addition of chondroitin sulphate A, B or C

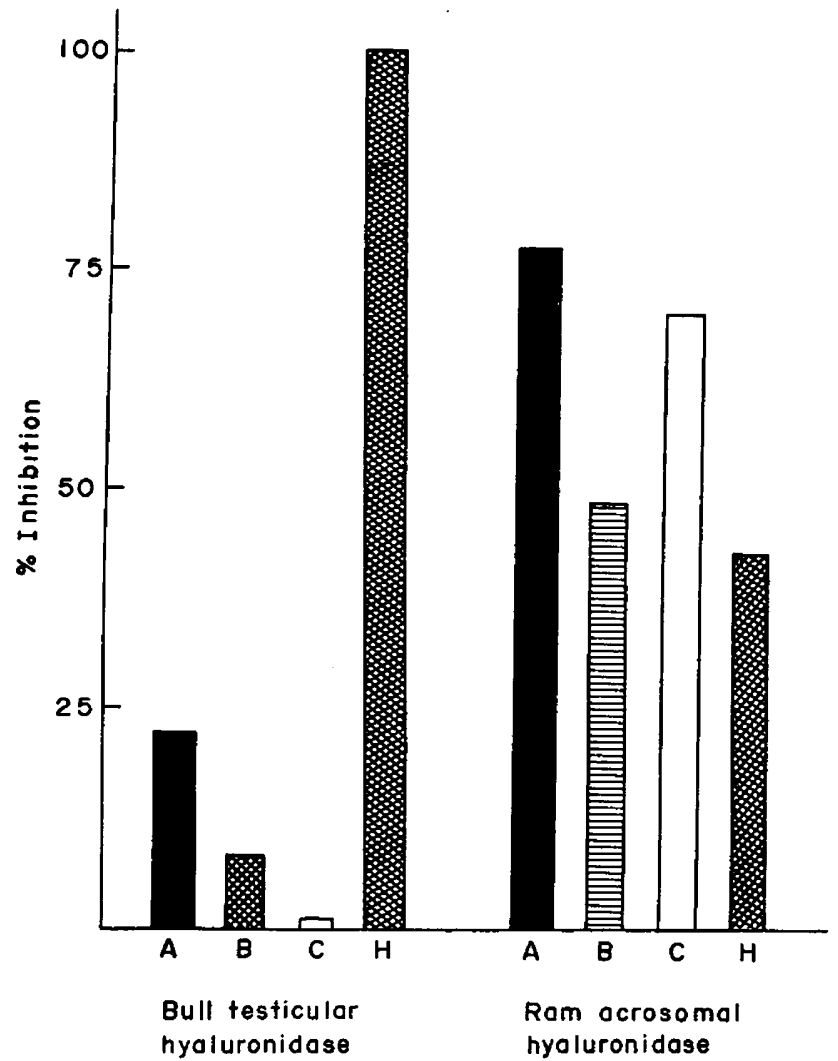

Text-Fig. 4. Effect of chondroitin sulphate A, B, C and heparin (H) $(0.6 \mathrm{mg} / \mathrm{ml})$ on bull testicular and ram acrosomal hyaluronidase activity ( $29 \mu \mathrm{g}$ protein) using hyaluronic acid $(0.6 \mathrm{mg} / \mathrm{ml})$ as substrate.

inhibits the enzyme reaction (Text-fig. 4). The substrate, hyaluronic acid, does not inhibit the enzyme activity up to the concentration of $1.8 \mathrm{mg} / \mathrm{ml}$. Higher concentration of the substrate is inhibitory. Bull testicular hyaluronidase is strongly inhibited by heparin.

Molecular weight estimation by sodium dodecyl sulphate gel electrophoresis. Purified ram acrosomal hyaluronidase $(30 \mu \mathrm{g})$ was applied on acrylamide gel after incubation with $1 \%$ SDS and $1 \% \beta$-mercaptoethanol. Reference standards were serum albumin (mol. wt 68,000), ovalbumin (mol. wt 43,000), pepsin (mol. wt 35,000), trypsin (mol. wt 23,300) and lysozyme (mol. wt 14,300). 
PLATE 1

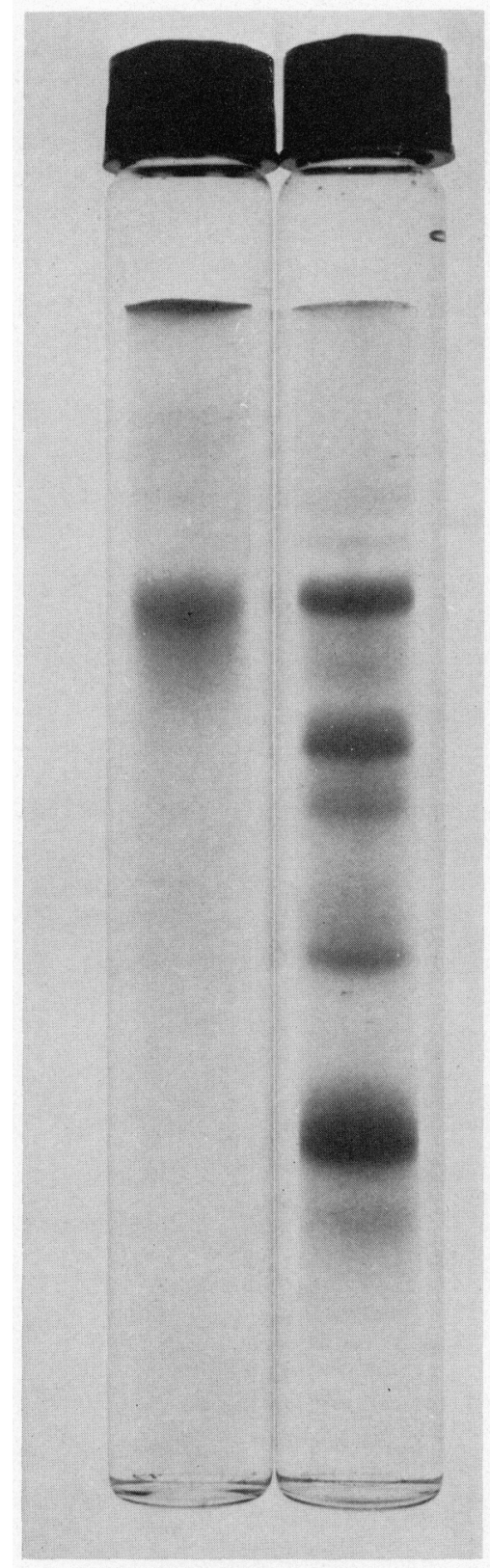

A

B

Ram acrosomal hyaluronidase migration pattern on sodium dodecyl sulphate gel electrophoresis obtained using $30 \mu \mathrm{g}$ sample and $10 \mu \mathrm{g}$ of each standard. A (left): Ram acrosomal hyaluronidase after DEAE chromatography. B (right): Standards: serum albumin (mol. wt 68,000), ovalbumin (mol. wt 43,000), pepsin (mol. wt 35,000), trypsin (mol. wt 23,300), and lysozyme (mol. wt 14,300).

(Facing p. 22) 


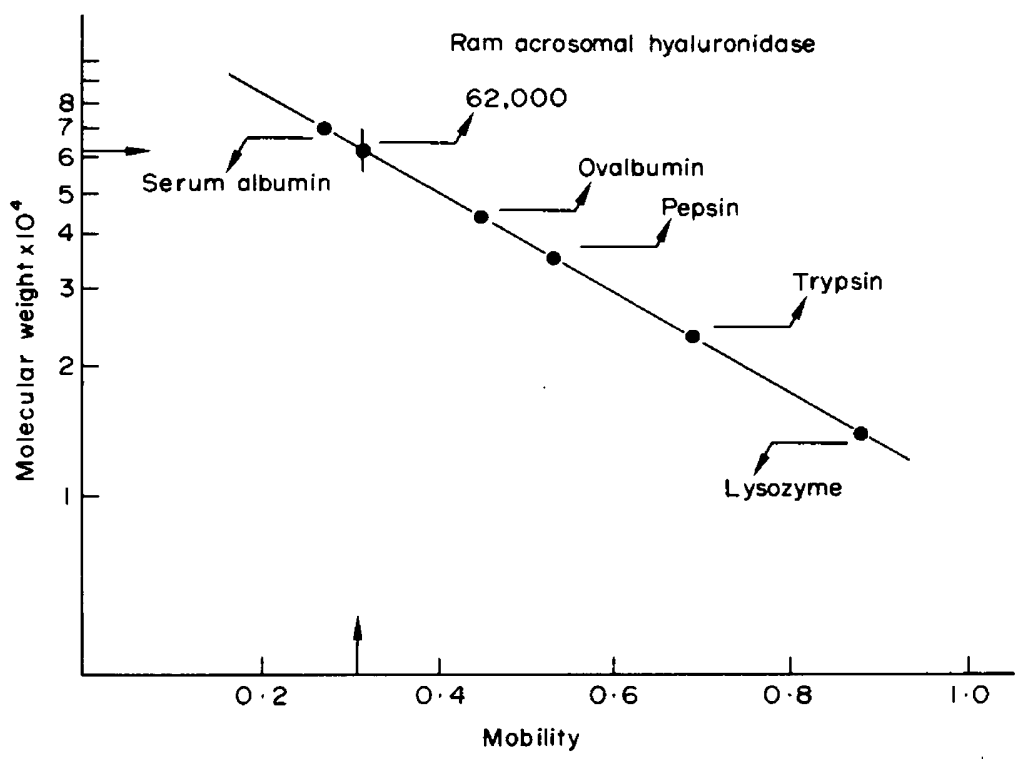

TEXT-FIG. 5. Molecular weight estimation of ram acrosomal hyaluronidase by sodium dodecyl sulphate gel electrophoresis. The enzyme obtained after DEAE chromatography was used (Step II).

Ram acrosomal hyaluronidase in gel A (Plate 1) is the major band. In gel B, the migration pattern of reference standards is shown. The mobility of the major band was plotted against the molecular weight on semi-log paper. As shown in Text-fig. 5 , the molecular weight of ram acrosomal hyaluronidase is 62,000 .

\section{DISCUSSION}

In the acrosomal extract of rabbit spermatozoa, hyaluronidase was claimed to be associated with a proteolytic enzyme (Stambaugh \& Buckley, 1969). At neutral $\mathrm{pH}$, ram sperm acrosomal hyaluronidase and acrosin are eluted from the Sephadex G-100 column in the same peak suggesting that the two enzymes have a similar molecular weight. Hyaluronidase and acrosin were separated on a long Sephadex G-100 column at pH 3.5 indicating absence of a complex at this $\mathrm{pH}$. Different molecular weights have been reported for hyaluronidases from different sources. Stambaugh \& Buckley (1969) reported a molecular weight of 59,000 for an acrosin-hyaluronidase complex of rabbit spermatozoa as determined by sucrose density gradient. However, Polakoski et al. (1972) reported that acrosin of rabbit spermatozoa has a molecular weight of 55,000. Borders \& Raftery (1968) found a molecular weight of 61,000 for bull testicular hyaluronidase as determined by gel filtration. Zaneveld et al. (1973) observed that bull sperm acrosomal hyaluronidase has a molecular weight of 110,000 as determined by gel filtration. The ram sperm acrosomal hyaluronidase has a molecular weight of 62,000. It seems probably that Zaneveld et al. (1973) 
determined the molecular weight of a dimer of the partially purified hyaluronidase. A small difference can be ascribed to the difference in methods used for estimating molecular weights. On the other hand, rat liver lysosomal hyaluronidase has a molecular weight of 89,000 based on sedimentation equilibrium data (Aronson \& Davidson, 1967a).

The modifications made in the colorimetric assay method may be responsible for observed high specific activity of ram acrosomal hyaluronidase. Compared to the partially purified bull sperm acrosomal hyaluronidase which has a specific activity of 3.5 by the colorimetric method and the crude acrosomal extract of ejaculated ram spermatozoa which has an average specific activity of 1.5 (Zaneveld et al., 1973), the crude acrosomal extract of ejaculated ram spermatozoa by the modified assay method has a specific activity of 112 . Low specific activity of acrosomal hyaluronidase of bull spermatozoa may partially be due to the leakage of hyaluronidase from spermatozoa in this species (Masaki \& Hartree, 1962).

Zaneveld et al. (1973) suggest that bull sperm acrosomal hyaluronidase is identical to bull testicular hyaluronidase. The molecular weight of ram sperm acrosomal hyaluronidase resembles that of the purified bull testicular hyaluronidase (Borders \& Raftery, 1968). Bull sperm acrosomal hyaluronidase, however, has an optimum at $\mathrm{pH} 3.75$ (Zaneveld et al., 1973), the testicularhyaluronidase has a broad $\mathrm{pH}$ optimum (Meyer, 1971) and ram sperm acrosomal hyaluronidase has an optimum at $\mathrm{pH} 4 \cdot 3$. Hyaluronic acid and chondroitin sulphate $\mathrm{A}, \mathrm{B}$ and $\mathrm{C}$ are the substrates for testicular hyaluronidase (Meyer, 1971) as well as for ram sperm acrosomal hyaluronidase. Aronson \& Davidson (1967b) reported that hyaluronate and chondroitin sulphate A and C are substrates for lysosomal hyaluronidase, while chondroitin sulphate B and heparin are inhibitors. They also observed that high concentrations of hyaluronate inhibit hyaluronidase, and chondroitin sulphate $A$ and $\mathrm{C}$ inhibit the activity of hyaluronidase when hyaluronate is used as the substrate. Chondroitin sulphate $\mathrm{A}$ and $\mathrm{C}$ inhibit ram acrosomal hyaluronidase activity when hyaluronate is used as substrate. Thus, ram sperm acrosomal hyaluronidase shares the properties of testicular and lysosomal hyaluronidase.

Metz (1972) states 'A definite answer to the question whether the antihyaluronidase antibodies are responsible or contribute to infertility will require the use of immunologically pure hyaluronidase as antigen'. In view of this, the importance of this work is obvious.

\section{AGKNOWLEDGMENTS}

This research was supported by Contract No. NIH-70-2147 with the National Institute of Child Health and Human Development and Ford Foundation Grant No. 680-0805A.

\section{REFERENCES}

Aronson, N. N., JR \& Davidson, E. A. (1967a) Lysosomal hyaluronidase from rat liver. I. Preparations. 7. biol. Chem. 242, 437.

Aronson, N. N., JR \& DAvidson, E. A. (1967b) Lysosomal hyaluronidase from rat liver. II. Properties. J. biol. Chem. 242, 441. 
Borders, G. L., JR \& Raftery, M. A. (1968) Purification and partial characterization of testicular hyaluronidase. 7. biol. Chem. 243, 3756.

Gornall, A. G., Bardawill, G. J. \& David, M. M. (1949) Determination of serum proteins by means of the Biuret reaction. 7. biol. Chem. 177, 751.

Hartree, E. F. \& SRivastava, P. N. (1965) Chemical composition of the acrosomes of ram spermatozoa. F. Reprod. Fert. 9, 47.

Lowry, O. H., Rosebrough, N. J., Farr, A. L. \& Randall, R. J. (1951) Protein measurements with the Folin phenol reagent. F. biol. Chem. 193, 265.

MASAKI, J. \& HARTREe, E. F. (1962) Distribution of metabolic activity, phospholipid and hyaluronidase between the heads and tails of bull spermatozoa. Biochem. 7. 84, 347 .

METz, C. B. (1972) Effects of antibodies on gametes and fertilization. Biol. Reprod. 6, 358.

MeYer, K. (1971) Hyaluronidase. In The Enzymes, Vol. V, p. 307. Ed. P. D. Boyer. Academic Press, New York.

Polakoski, K. L., Zaneveld, L. J. D. \& Williams, W. L. (1972) Purification of a proteolytic enzyme from rabbit acrosomes. Biol. Reprod. 6, 23.

Reissig, J. L., Strominger, J. L. \& LeLoir, L. F. (1955) A modified colorimetric method for the estimation of N-acetylamino sugars. 7. biol. Chem. 217, 959.

Schwert, G. W. \& TAKenaKa, Y. (1955) A spectrophotometric determination of trypsin and chymotrypsin. Biochim. biophys. Acta, 16, 570 .

Srivastava, P. N., Adams, G. E. \& Hartree, E. F. (1965) Enzymatic action of lipoglycoprotein preparations from sperm acrosomes on rabbit ova. Nature, Lond. 203, 498.

SRivastava, P. N., Zaneveld, L. J. D. \& Williams, W. L. (1970) Mammalian sperm acrosomal neuraminidase. Biochem. biophys. Res. Commun. 39, 575.

Stambaugh, R. \& Buckiey, J. (1968) Zona pellucida dissolution enzymes of the rabbit sperm head. Science, $\mathcal{N} . \Upsilon .161,585$.

Stambaugh, R. \& BuckLey, J. (1969) Identification and subcellular localization of the enzymes effecting penetration of the zona pellucida by rabbit spermatozoa. F. Reprod. Fert. 19, 423.

Weber, K. \& OSBORN, M. (1969) The reliability of molecular weight determinations by dodecylsulphate polyacrylamide gel electrophoresis. 7. biol. Chem. 244, 4406.

Zaneveld, L. J. D., Polakoski, K. L. \& Schumacher, G. F. B. (1973) Properties of acrosomal hyaluronidase from bull spermatozoa: Evidence for its similarity to testicular hyaluronidase. F. biol. Chem. 248, 564 .

Zaneveld, L. J. D., Polakoskr, K. L. \& Williams, W. L. (1972) Properties of proteolytic enzyme from rabbit sperm acrosomes. Biol. Reprod. 6, 30. 